\title{
A Reflection of the Use of the Life Cycle Assessment Tool for Agri-Food Sustainability
}

\author{
Oriana Gava *๑), Fabio Bartolini $\odot$, Francesca Venturi $\odot$, Gianluca Brunori $\odot$, Angela Zinnai and \\ Alberto Pardossi (i) \\ Department of Agriculture, Food and Environment, University of Pisa, 56124 Pisa, Italy; \\ fabio.bartolini@unipi.it (F.B.); francesca.venturi@unipi.it (F.V.); gianluca.brunori@unipi.it (G.B.); \\ angela.zinnai@unipi.it (A.Z.); alberto.pardossi@unipi.it (A.P.) \\ * Correspondence: oriana.gava@for.unipi.it
}

Received: 11 October 2018; Accepted: 20 December 2018; Published: 23 December 2018

check for updates

\begin{abstract}
In pursuit of agricultural sustainability and food security, research should contribute to policy-making by providing scientifically robust evidence. Life cycle assessment (LCA) is an excellent candidate for generating that evidence, thereby helping the selection of interventions towards more sustainable agri-food. The purpose of this article is proposing a basis for discussion on the use of the LCA tool for targeting and monitoring of environmental policy interventions in agri-food. The problem of reducing the environmental burden in agri-food can be tackled by acting on the supply and/or demand sides and may benefit from the collaboration of supply chain stakeholders. Agri-food policies that most benefit from LCA-based data concern cross-border pollution, transaction costs following the adoption of environmental standards, adoption of less polluting practices and/or technologies, and business-to-consumer information asymmetry. The choice between the methodological options available for LCA studies (attributional, consequential, or hybrid models) depends on the purpose and scope of the study. The possibility of integrating the LCA with economic and social impact assessments-e.g., under the life cycle sustainability assessment framework-makes LCA an excellent tool for monitoring business or sectoral-level achievements with respect to UN 2030 Sustainable Development Goals.
\end{abstract}

Keywords: sustainable development goals; sustainability assessment; agricultural sustainability; food security; LCA broadening; LCA deepening

\section{Introduction}

\subsection{Background and Rationale behind the Study}

The design and implementation of policy strategies towards agricultural sustainability and food security should base on scientific evidence, to guarantee environmental protection and avoid burden sharing, without reducing the productivity, competitiveness, and profitability of agri-food [1], thereby allowing to meet UN 2030 Sustainable Development Goals (SDGs), especially three interrelated goals, i.e. SDG2, SDG13, and SDG15 [2,3]. The aim of SDG2 (no hunger) is to promote profound changes in the way food is produced and consumed, for feeding the growing world population. Specific targets involve ensuring sustainable food production systems and implementing resilient agricultural practices, while doubling the agricultural productivity and farmers' incomes. SDG13 (climate action) has the objective of limiting the global temperature to rise. To that purpose, national governments are called to implement climate mitigation policies and adaptation policies to promote the resilience and adaptive capacity of socio-ecological systems. SDG15 (life on land) aims at preserving forests and preventing desertification, land degradation, and biodiversity loss. The goal includes the promotion 
of measures for preserving ecosystems and encourages governments to integrate ecosystem and biodiversity values into national and local planning and development programs.

Among the sources of scientific evidence, information generated via life cycle assessment (LCA) has received growing attention by policy-makers for identifying, selecting, and guiding interventions to reduce the environmental burden of agriculture and food systems $[4,5]$, as well as for setting the objectives and monitoring the impacts of policies [6,7]. LCA is a formalized method (ISO 14040:2006; ISO 14044:2006) (ISO, Geneva, Switzerland) and can be applied for monitoring the achievements of the agricultural sector or single business with respect to SDGs [8]. Policy instruments based on LCAs of traded commodities can mitigate carbon leakage and reduce food losses, by affecting producer and consumer price, thus altering food production and consumption decisions $[9,10]$. Various governments have set up publicly-available life cycle inventory databases for agricultural activities (e.g., the USA [10], Australia [11], France [12]) and regularly require LCA in their funded research projects [13]. Public investments in LCA research have helped the creation of the scientific knowledge base for evidence-based policy-making [14].

A simple search ("life cycle assessment" AND "agriculture") over major academic citation indexes (viz. Scopus ${ }^{\circledR}$, Web of Science ${ }^{\mathrm{TM}}$ ) reveals the substantial and recent growth of LCA-based agricultural research, including variously structured literature reviews. Refereed original research has covered the impacts of major agricultural production systems (at least in advanced economies) and has been largely synthesized to highlight, for example, the impacts associated with the production of food [15]—including insects [16] and biofuels [17]—of management practices [18], and of human diets [19], among others. Despite the wide scope for LCA application and development and the growing interest by governments and the research community [20,21], LCA applications targeting the decision-making process in agricultural policy is not so developed, when compared to other economic sectors., with theoretical analyses being almost missing (see [22] for a notable exception). The purpose of the article is not providing a systematic review or meta-analysis of impacts, which are already available from the literature, e.g. $[23,24]$. Rather this article focuses on needed research development to improve the policy orientation of LCA findings. In a forthcoming study, we will expand on the objective of the present article by delivering a content analysis-based literature review of the academic literature with explicit implications for agricultural policy community, focused on needed research development to improve the policy orientation of LCA findings. Policy interest is among the drivers of LCA popularity in agri-food research [20,25]. Despite that, much more research is needed to adapt LCA studies to policy demand. Key challenges involve adopting innovative perspectives on intervention strategies [26], improving data sources [25], as well as deepening and broadening the LCA technique $[27,28]$. Drawing on those challenges, this article covers a series of aspects of LCA application, namely research perspectives towards the mitigation of the environmental burden of agricultural and food systems, the scope of the practical use of LCA-based information for regulatory purposes, as well current obstacles to method diffusion and the opportunities for improvement. The aim of the article is to propose a basis for discussion on the use of the LCA tool for targeting and monitoring environmental policy interventions in agri-food, by bringing together and discussing different theoretical and practical elements that should be considered when envisioning LCA studies for agri-food sustainability, some of which were individually addressed by previous research (e.g., [5,20,25,26,28,29]).

The paper aims at inspiring and promoting policy-oriented LCA research, thereby targeting both researchers and policy makers.

\subsection{Article Outline and Conceptual Model}

A mutual relationship exists between the decision-making process and the evidence generated in LCA studies, with practitioners needing to adjust the methodological approach based on the final use of LCA outputs [30,31]. Figure 1 provides a conceptual representation of different elements of the that relationship. 


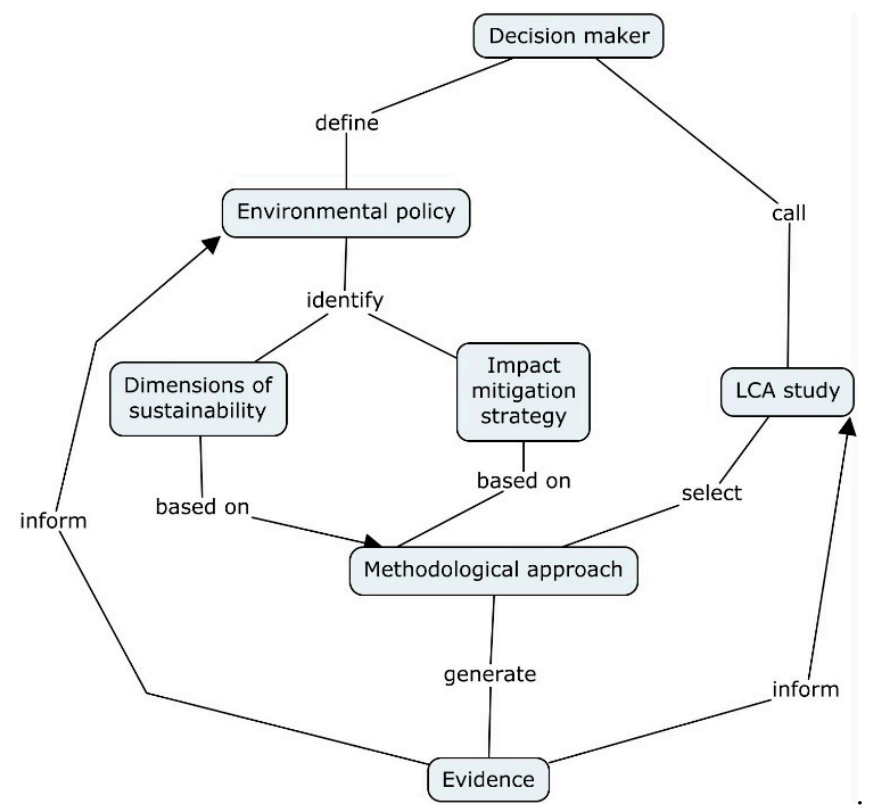

Figure 1. Conceptual model: mutual relationships between the different sections of the article. Source: Authors' own elaboration.

A key determinant of method and data source selection is decision-maker approach to impact mitigation, which identify the stakeholders that are requested to implement actions aimed at impact reduction. For example, technological innovation on firm may allow to reduce the environmental burden of food supply. Contextually, adopting green marketing strategies to inform consumers about the adoption of impact mitigation actions (e.g., food labelling) may increase the consumption of more ecological foods. The type of application of LCA-based information is another determinant of method selection. For example, decision-makers might be interested in learning the impacts of a new technology or in comparing the impacts of two alternatives. When the focus is wider than the business-level, decision makers might be interested in wider impact assessments, including for example economic and social impacts. The role of research is addressing the limitation of the method to improve the reinforcing feedback loops between existing LCA frameworks and decision makers against that background.

Based on the conceptual model above, the present article is structured towards five more sections. The next section provides a synthetic overview of the LCA method, focusing on the key elements that distinguish major methodological approaches. The following section presents the approaches to impact mitigation in agriculture and food systems. Section 4 concentrates on the practical application of LCA-based information for public and private policy. Section 5 addresses method related limitations and presents a series of approaches for dealing with those limitations. The last section presents a discussion of the state-of-the art and delivers some recommendations.

\section{Overview of the Method}

LCA is the most comprehensive technique for tracing and generating quantitative information about the environmental burdens that originate from the activities and facilities involved in manufacturing, delivering, consuming, and managing the end-of-life of production processes or of the average or marginal output of an industry, i.e., from cradle-to-grave [32]. The assessment has been formalized by the International Standard Organization (ISO) (Geneva, Switzerland). Two ISO (Geneva, Switzerland) rules provide general guidelines for the assessment, thereby allowing great flexibility to practitioners. ISO 14040 (2006) (ISO, Geneva, Switzerland) delivers the principles and the framework for the assessment, including the stepwise procedure, LCA reporting and critical review, limitations of the assessment, and conditions for use of value choices and optional elements. ISO 14044 
(2006) (ISO, Geneva, Switzerland) delivers a general guideline to the stepwise procedure, though not providing methodological details about the practical implementation of LCA steps.

LCA is based on an iterative process with four steps, i.e., goal and scope definition, inventory analysis, impact assessment, and interpretation. Based on the goal and scope, the assessment may be narrowed to exclude upstream processes (gate-to-grave), downstream processes (cradle-to-gate) or both (gate-to-gate), or even to exclude the impact assessment step. The latter are more properly referred to as life cycle inventory studies. Life cycle inventories are datasets that account for all material and energy flows and related emissions (via the application of characterization factors), through the various processes within the system boundaries. Input flows refer to consumed natural resources, materials and energy, output flows account for waste, emissions to air, water and soil, and the final goods and services being produced. Input-output flows include variables that should be included in the inventory - e.g., productivity, distance travelled, and type of transport-among others [31]. Based on the part of the system that is under the direct influence of the decision maker, the product system under study can be divided into foreground and background subsystems. The former includes the processes that are directly affected by the decisions made in the study, both in terms of process type and mode of operation; the latter includes the processes aimed at supplying material or energy to the foreground subsystem [30]. When possible, the description of the foreground subsystem should rely on primary data, while secondary or generic data can be used for the background subsystem [31]. Primary data can be directly gathered-e.g., from farmers, food processors or other stakeholders, including consumers-and may be aggregated or concern individual companies. Secondary data can be collected from different sources, such as, for example, scientific literature, business or government reports. In addition, many life cycle inventory databases are available, such as Ecoinvent ${ }^{\circledR}$ and Agrifootprint ${ }^{\circledR}$. As far as possible, inventories of foreground subsystems should rely on site-specific data [33], though average or generic data may be preferred, depending on research aims [34].

Impact categorization and characterization occurs in the impact assessment step, via the application of impact assessment models. The outputs cover a wide set of problem-oriented (midpoint) or damage-oriented (endpoint), grouped under various impact categories, covering the depletion of natural resources and damages to the environment and human health (an example of recommendations about model and impact category selection is available from [31]). Via contribution analysis, LCA outputs may be used for identifying the activities that most contribute to the environmental impacts of a given product (hot spots), thereby facilitating the targeting of impact mitigation interventions at the sectoral or business-level [29]. Stand-alone LCAs concentrate on a single product, generally for exploratory purpose, while comparative studies aim at supporting product selection [35]. Assessments covering single issues are known as footprint studies. Carbon and water footprints are popular formalized methods (ISO 14067:2018 and ISO 14046:2014, respectively (ISO, Geneva, Switzerland) for calculating and communicating the greenhouse gas emissions and freshwater consumption associated with product life cycles [36]. Footprints are widely used for informing consumers about the environmental performance of foodstuffs via food labelling.

The most widespread software programs for supporting product system modeling and assessment by LCA practitioners are SimaPro ${ }^{\circledR}$ and $\mathrm{GaBi}^{\circledR}$, though other software programs exist, e.g. openLCA ${ }^{\circledR}$ or Umberto ${ }^{\circledR}$. Software solutions include major life cycle inventory databases and impact assessment models. LCA software tools are generally distributed under a licensing agreement to users, which implies the payment of a fee, though open source software exists, notably openLCA ${ }^{\circledR}$. Besides publicly available life cycle inventory databases, access to commercial databases (e.g., Ecoinvent ${ }^{\circledR}$ ) is generally necessary for gathering data about background subsystems.

Conceptually, LCAs are divided into retrospective and prospective. Retrospective LCAs, or LCAs of the accounting type [30], aim at describing the production of a given product in a system in terms of materials and energy flows, before or after impact mitigation interventions, and the associated environmental impacts; the latter are calculated based on average emissions for producing a unit of the product in the system [37]. Prospective, or change-oriented [30], LCAs consider the environmentally 
relevant flows in the production of a given product, for describing the consequences of possible impact mitigation interventions (e.g., future policy), i.e., the effects of substitutions in the relevant material and energy flows [37]. In prospective LCAs, system boundaries are expanded, even outside cradle-to-grave system of the product under study, to include the activities introduced via substitution and the associated emissions, with data referring to unitary changes in the relevant flows (marginal data) $[30,37]$. Prospective LCA studies are especially suited for product development and the ex-ante evaluation of public policies [35].

The division between retrospective and prospective LCA underpins the difference between the attributional (ALCA) and consequential (CLCA) LCA models, respectively. ALCA is the conventional model—formalized in the 1990s (ISO 14040: 1997) (ISO, Geneva, Switzerland)—which provides a static picture of the impacts associated with all the processes included in the boundaries of the system under study. CLCA — formally defined only in 2011 [38] — was developed for creating the connections between environmental and economic models [39]. The purpose of CLCA is to quantify the market-mediated consequences of decisions (measures to mitigate the environmental impact of productive activities) concerning the system under study on other systems [5]. Instead of the processes included in the real (or proposed) production system, CLCA studies, model the systems that are more likely to respond to changes in demand due to the decisions taken to reduce the impacts on the environment (marginal systems) [40]. For example, the diffusion of biogas-to-energy plants based on agricultural biomass can reduce the demand for electricity from the national energy mix [41]. CLCA studies should consider the interactions between agricultural and food policies and changes in consumer behavior [5]. Besides the main product, agricultural supply chains often include intermediate products and by-products (multifunctional processes), for example, calves in the production of cow's milk. ALCA and CLCA differ for the applied method for calculating the emissions associated with multifunctional processes. The attributional model is usually based on allocation, the consequential on system expansion. The allocation method relies on emission distribution among main products, intermediate products and by-products, based on physical properties, such as mass or gross energy, or the market value of the three types of output. The system expansion method considers intermediate products and by-products as resulting from independent (external) production processes, i.e., different from the production process that originate the main product. Those external processes turn to be included within system boundaries, their relative impacts are calculated and subtracted from those of the multifunctional process (saved impacts). CLCA is broader in scope than ALCA, accounting for the horizontal linkages (e.g., competition for a good in alternative applications) at each step in the supply chain, whilst ALCA concentrates on the vertical dependencies throughout the chain [42]. Moving to impact assessment, life cycle impact assessment models for consequential studies model the consequences of one additional unit of a given emission, rather than the average consequences of all emissions [43]. The main drawback of CLCA is the high number of economic assumptions, which grows easily with the number of processes included in the boundaries of the system and may be an important source of variability in study results [44]. Many authors contrasted the key features of attributional and consequential LCAs, in terms of aims of the studies, inputs from and implications for decision-making, and methodological choices, including the way how systems are modeled [30,43,45-48]. The comparative appropriateness and the potential for the complementary use of the two LCA models for political applications are the subject of an open debate within the scientific community $[42,44,49,50]$.

ISO 14040:2006 and 14044:2006 (ISO, Geneva, Switzerland) refer to ALCA and CLCA. Another major approach to LCA exists that has not been covered by ISO (Geneva, Switzerland) rules-i.e., sector-based LCA, known as economic input-output LCA (EIO-LCA). EIO-LCA is an economy-wide assessment of the environmental burdens caused by the business sector, its suppliers and suppliers' suppliers. The assessment adopts a top-down approach by relying on economic input-output analysis for tracing the interdependencies among economic sectors in a given region and giving the transactions an economic value [51]. Sectoral level data from national economic input-output tables are extended by adding a vector of total domestic direct and indirect environmental burdens, e.g., resource use or 
emissions [52]. Generally, input-output tables do not cover the use and waste management phases of products. Process-based data are often used to cover those life cycle stages. Hybrid LCA links process-based (conventional) LCA with EIO-LCA. EIO-LCA is especially useful when real-world data about given products and processes are not accessible and/or when practitioners are not familiar with the characteristics of a certain industry [50]. However, process-based LCA, i.e. that quantifies the impacts based on physical relations between activities in across product life cycle as standardized in ISO (Geneva, Switzerland) rules, and EIO-LCA have opposite perspectives and different levels of data resolution, which makes the selection of the approach strictly dependent on the objective of the study, as well on its intended audience [51]. The works of [43,51] compare the key features of LCA and EIO-LCA, evaluate their suitability for impact assessment at different level of analysis, and provide recommendation for application.

\section{Approaches to Impact Mitigation Strategies in Agriculture and Food Systems}

Strategies to reduce the environmental impact of agricultural and food systems involve targeting actions to the supply and/or the demand sides. The former includes the promotion of practices that improve the environmental performance of agriculture, while preventing negative effects on productivity [26]. The purpose of LCA studies is identifying hot spots and comparing management or technological options for improving the environmental performance of single businesses or of the whole sector $[13,53]$. For example, food packaging has received special attention by the food industry [25]. The life cycle impacts of packaging grow with product water content [54] and, e.g., account for most impacts of wine, especially due to the production and disposal of glass bottles [55]. However, wine consumers may not be willing to accept different packaging materials (e.g., plastics) [56]. So far, supply-side actions have received the greatest attention by researchers [26].

Largely policy-driven, demand-side actions aim at changing consumption patterns to reduce the demand for the most impacting foods [57], e.g., products of animal origin (in particular dairy products and meat of ruminants), those deriving from conventional agriculture $[58,59]$ or that require water-intensive agronomic practices (e.g., rice) [60]. The reduction of food waste is an additional demand-side strategy [57], which, however, has shown a limited impact mitigation potential compared to dietary change [61]. The adoption of impact mitigating practices and/or technologies still occurs in the supply side, but their implementation is mediated by market forces [26]. Regulatory options to promote changes and encourage sustainable consumption generally involve acting on consumer information and education, to raise awareness and policy acceptability [62]. LCA applications involve the comparison of different consumption patterns via the calculation of environmental/nutritional trade-offs associated with the reduction, removal, or substitution of animal-based foods [63]. Compared to supply-side actions, research focusing on the demand side is more recent and has raised the interest and support of more and more research [25]. A key challenge involves addressing the feedback loops between dietary alterations for human health. The LCA literature contributed to answering that challenge mainly by assessing the environmental impacts of diets differing in the content of meat and dairy or by assessing environmental impacts of healthier diets [63]. The former generally compare current consumption patterns (i.e., self-selected diets, generally based on food consumption surveys) against official dietary guidelines and/or other popular type of diets (e.g., vegetarian). The second strand of literature has the nutritional quality of the assessed diets at its core (e.g., [64]). Mainly, the authors propose considering the restriction of the total energy intake as an impact mitigation strategy and to carefully model the choice of meat replacement foods, to avoid burden shifts associated for example with the consumption of greater quantities of food, due to the lower energy density, and of the increased demand of imported or out-of-season foods [65].

Supply and demand side approaches could be combined to promote system-level actions, subject the communication and collaboration among the involved stakeholders [26], such as private businesses (supply side), the public (demand side), governments (resource-use regulation), and researchers and practitioners (impact assessment and monitoring) [66]. To that purpose, the conceptualization and 
implementation of LCA studies should concern redesigned models of agricultural and food systems (scenarios) that propose sustainable synergetic solutions [61,67]. An example of agri-food system redesign involves the application of the concept of "ecological leftovers" [68], which, though promising, needs more empirical research to be effectively proposed for real world applications, especially for knowing more about its cultural acceptability [69].

\section{Policy Applications of LCA Results}

Information originating from LCA studies is used in policy-making to face four broad challenges, viz. pollution leakage, ex-post transaction costs of environmental regulation, adoption of environmentally least harmful (technological) options, and business-to-consumer information asymmetry [20]. Pollution leakage is the increase in total pollution outside the policy jurisdiction where the investigated process occurs, in response to a decrease in total pollution within the same jurisdiction, which, e.g., could occur in case of indirect land use change from food to energy cropping [70]. The costs of administration, monitoring, and enforcement of environmental regulation can be high when (potential) polluters are many and heterogeneous, thus making emission monitoring a very costly activity [20]. On one hand, transaction costs may be reduced by monitoring a set of key upstream activities that produce widespread raw materials, e.g., fossil fuels [71]. On the other hand, extended producer responsibility policies have grown in the last two decades, which give producers a significant financial and/or physical responsibility for the treatment or disposal of post-consumer products, in exchange of incentives to prevent waste creation and promote eco-friendly product design [72]. Policy support of the adoption of environmentally least harmful options is widespread across countries (for example, the payments to farmers that adopt practices beneficial for the environment under the Common Agricultural Policy of the EU [73]) and may encompass incentives for developers and / or adopters of innovations [74]. Business-to-consumer information asymmetry occurs when the attributes of products are credence qualities; eliciting information about some of those attributes through environmental labelling reduces information asymmetry, by providing the product with experience qualities, e.g., implemented production practices, emissions occurred during production, type of energy sources, water consumption, among others [75]. However, the effectiveness of environmental labels in conveying the intended information and orienting consumption patterns are subject to consumer education and proper label design [76,77].

To face the four challenges above, [20] classified the application of data generated via LCA (stand alone, retrospective or prospective studies) under three domains, i.e., pure information for decision makers, passive regulation, active regulation. The first type of application is generally intended for providing decision-makers with new knowledge about the impacts of existing or innovative products, practices or technologies. This can be done via stand-alone or comparative LCAs [35]. Passive regulation applications aim at informing the choice among multiple options (e.g., processes, scenarios). Data can be used to target public support towards specific products, technologies, production practices, or end-of-life management via recommendations, labelling or qualification schemes, mandatory targets or incentives to production/consumption of a given product. Lastly, LCA can drive active regulation when highlighting specific parameters that can form the basis, e.g., for an incentive, tax, or subsidy, or for the design of an environmental performance standard. To inform passive or active regulation, LCA studies should be comparative prospective or retrospective [35]. Within the domains of passive and active regulation, policy and business decision makers may also benefit from further elaborations of LCA outputs, e.g., when needing to consider consumer preferences. Food labelling is a typical example, as label design and the way how information about products' emissions (e.g., qualitative or quantitative information) is presented affect consumers' choices [77]. To identify preferences, behavioral economists generally evaluate consumers' willingness to pay for different food/label attributes. This research approach can also evaluate whether adopting a given labelling scheme is an effective differentiation strategy for farmers and what price premiums can be applied to least emitting products [78]. 


\section{Limitations of the Method and Opportunities for Improvement}

LCA has evolved from a tool for managing resource use on firm, through a method for monitoring energy use over the production process and for complying with overarching emission reduction mandates, to a metric that drives and is embedded in policy-making [5], including policy evaluation [6,7]. However, a series of improvements may benefit the diffusion of the tool, especially concerning study harmonization, data issues, and the inclusion of economic and social aspects.

\subsection{Study Harmonization}

Besides data sources, the flexibility of ISO (Geneva, Switzerland) rules has raised concerns about the credibility, transparency, complexity, and communication ability of LCA studies, which can possibly interfere with LCA applications for policy and strategic planning [5]. For example, ISO (Geneva, Switzerland) do not strictly specify how to define the functional units or reference flows and system boundaries, how to select the rules for quantifying the impacts associated with multifunctional processes or how to establish the environmentally relevant impact categories. This wide margin of discretion left to practitioners has been seriously criticized, because the operational choices can generate different and often incomparable results [79]. To overcome those issues, ISO (Geneva, Switzerland) guidelines should be deepened, i.e., revised to include more detailed definitions and stricter rules, to allow greater uniformity among the architecture of different LCA studies, thereby improving the reliability and comparability of findings, as well as widening the scope of results applicability [80]. Trying and answer the need for greater harmonization in the analytical protocols of LCA studies, the European Commission's Joint Research Centre proposed detailed guidelines for the calculation of products' life cycle impacts (Product Environmental Footprint; Recommendation 2013/179/EU). The adoption of a voluntary environmental certification based on LCA (Type III Environmental Declarations ISO 14025:2006, which base on LCA) (ISO, Geneva, Switzerland), also implies the compliance with stricter rules than the ISO (Geneva, Switzerland), providing guidance on data quality requirements and on the selection of environmentally relevant impact categories, among others. The Environmental Product Declaration $\left(\mathrm{EPD}^{\circledR}\right)$ and the Carbon Footprint of Products are examples of those certifications. Certification adoption by a company allows the producer to provide the product with environmental claims and facilitates comparative assertions.

\subsection{Data Issues}

LCA is a data-intensive method. Gathering all the necessary data to carry out the assessment is not an easy task. Data originate great concerns within the research community. Primary data collection can be prohibitively expensive [10] and often secondary data cannot cover the lack of information about the processes under study [25]. For agri-food databases, greater transparency is required on data collection, the harmonization of different databases, to facilitate the use of more than one of them, the definition of net boundaries between the technosphere and the ecosphere and the incorporation of spatial variability [25]. The databases should also be updated with innovative and pilot technologies currently available to entrepreneurs [13] and allow their users to address cross-cutting issues, such as food losses along the supply chain, end-of-life treatment technologies [81,82], and the impact of different packaging materials [81,83]. Such improvements are additional aspects of LCA deepening [80].

\subsection{Inclusion of Economic and Social Aspects}

Another problem of LCA studies is being limited to environmental aspects, omitting economic and social aspects, of great importance to decision makers [79]. The approach for overcoming this problem, known as broadening, involves extending the analysis to the economic and/or social dimensions of sustainability [80]. Research approaches to LCA combinations with various economic assessment and decision-support tools are not recent-e.g., multicriteria decision making analysis [84], stochastic optimization [85], full cost accounting [86] —and have been extensively 
reviewed [87]. When one can assume a fixed structure of the economy, many authors have turned to environmental input-output-LCA (EIO-LCA) [88-91]. EIO-LCA can eliminate the arbitrariness in system boundary's definition, thereby helping to cope with truncation errors [92]. LCA combination with data envelopment analysis (DEA) is promising, by linking engineering, life sciences, and social sciences, and delivering estimates over the three dimensions of sustainability, thereby improving policy targeting [13,93]. Many examples of LCA combinations with DEA are available from the scientific literature [94]. Compared to other economic sectors, combined DEA-LCA studies in agri-food are few (see [95] for an example). Further improvements may arise from the use of system dynamics modelling to correct model estimates, e.g., with respect to temporal effects, rebound effects, and uncertainty [96]. Compared to economic aspects, LCA combination with social impact assessments has received less attention by researchers, though being key to allow consumer acceptability of innovative food production and consumption systems [69]. The growing popularity of life cycle sustainability assessment (LCSA) has mitigated this knowledge gap, by promoting the combination of LCA with life cycle cost accounting (life cycle costing) and social LCA. LCSA has raised the interest of policy makers, delivering synthetic information on the three dimensions of sustainability that largely base on the same data sources $[97,98]$. The availability of data on impacts on several dimensions is particularly important in the assessment of debated innovations, for example in the context of the bioeconomy [13]. The adoption of a more holistic methodological approach would also allow to consider the possible effects associated with changes in the use of production factors and yields of production processes, resulting from the large-scale implementation of environmental mitigation measures (rebound effects) [22]. Especially, the adoption of participatory approaches may help with the identification of rebound effects and the possible ways to address them, via the collaboration among supply chain stakeholders, consumers, authorities, and waste-handlers [81]. LCA applications under this perspective need further research, especially for developing indicators against which to measure progress, for incorporating concepts such as human agency and moral responsibility, and for considering the dynamic interactions between economic values and health outcomes of different production systems [26].

\section{Discussion and Recommendations}

The scientific literature proposes to address the necessary reduction of the environmental impacts agriculture and food systems via the public support to innovation (practices, technologies) to improve resource management efficiency on firm (supply-side), or to facilitate the change in food consumption patterns with indirect effects on food supply (demand-side), or to interventions addressing both the supply and demand-sides that require the collaboration of supply chain stakeholders (system level interventions). LCA is a scientifically robust tool for calculating the impacts of agricultural systems, affected or not by pollution reduction measures. LCA studies investigate and/or compare and immediately communicate the environmental impacts of-e.g., farming methods, input management systems, technologies, or consumer behavior-and can support evidence-based policy making in agriculture and food systems. Information about product impacts can help to provide the basis for establishing legal limits on emissions (e.g., carbon tax) or entry levels to access public tenders (e.g., green public procurement). In agri-food, the policies that benefit most from such information concern cross-border pollution, transaction costs associated with the application of environmental standards, the adoption of less polluting practices or technologies, and the reduction of information asymmetry business-to-consumer. Given the growing consumer sensitivity towards the environmental impacts of agri-food products, environmental certifications and labelling are the most significant example of the opportunities LCA offer to the agribusiness, in terms of product positioning on the domestic and export markets. Concerned consumers are willing to pay a price premium for environmental label on foods $[78,99]$. However, labels' effectiveness in orienting consumer decisions does not depend just on the type of impact information conveyed [76]. Often, consumers are not aware of the estimates behind the label; moreover, multiple labels exit that can create consumer confusion. Confusion may also arise between environmental declarations (product certifications) and process certifications, e.g., organic 
farming [100]. Then asymmetric information remain unsolved [101]. Label design is critical to allow the clarity of information delivery and then reduce consumer confusion [102]. Labels should help comparisons within and across food products, use consistent and accessible units of measure, be able to communicate the sustainability criteria behind footprint calculation [77]. Coherent, comprehensive, and cohesive carbon labelling policy, coupled with dedicated social learning campaigns, may help to achieve policy objectives [76,103]. In addition, policy makers should monitor the proliferation of sustainability labels, to play a credible and appropriate role in the development of certification schemes [99].

Improving product positioning is the main drivers for entrepreneurs to adopt an environmental certification [104]. However, certification adoption implies a series of costs associated with the adoption itself and with the requirements the firm need to meet through time to be eligible for the certification scheme, including the adaptation of production facilities [105]. More studies are needed that consider the combined environmental, economic, and social impacts of certification adoption in agribusiness, to evaluate the extent to which the value added associated with certification adoption can be distributed among supply chain stakeholders and to verify if farmers are incentivized to modify their production practices and technologies or are "forced" by the market [106]. Food labels allow the direct comparison of substitutes. However, the extent to which food labels can influence purchasing decisions depends not only on the clarity of the conveyed information, but also on consumers' ability to understand that information [76]. Therefore, entrepreneurs in the agri-food sector wishing to promote their products as "ecological" should pay attention to consumer attitudes, to decide on the type of information and the way how to present it via label design for encouraging purchases [77]. The implementation of consumer education campaigns could improve the effectiveness of demand-side interventions [103]. This is especially relevant when it comes to the promotion of sustainable diets $[63,69]$.

While the high environmental impacts of ruminant meat consumption are recognized, many studies assume that the adoption of more plant-based diets may benefit both health and the environment, without considering the energy density of meat-replacement foods [63]. Besides, decision makers and researchers should consider the potential risk for nutrient deficiencies and the resulting potential increase in the demand for fortified foods or food supplements [107]. To allow the effective promotion of new dietary models, more LCA studies are needed that consider the trade-offs between impact mitigation and health and nutritional outcomes of dietary shifts, also by adopting an epidemiological approach [65]. To inform evidence-based policy, the LCAs of diets should be based on more insightful indicators of nutritional quality, rather than just focusing on macronutrients [65]. More consumer studies are needed to assess the cultural acceptability and affordability of low impact diets $[65,69]$.

Researchers' choices among the several methodological options for carrying out a LCA depend on the purpose and scope of the study. CLCA should be preferred when it is necessary to link environmental and economic models, while EIO-LCA can be useful to correct for method limitations, in specific circumstances [108]. In general, LCA is not without criticism [21] and alternative approaches had many applications in agricultural research, e.g., multi-region input-output analysis [109,110], data envelopment analysis [111], or structural path and structural decomposition analyses [112], among others.

LCA is just one the many sustainability assessment tools and different classifications frameworks exist (see [113] for an overview). For example, indicator-based assessments rely on sustainability indicators, presenting simple information, generally quantitative, about a state of economic, social and/or environmental development in a given region, which may be useful for communicating trends and for non-specialized audience [114]. Monetary assessments, notably cost-benefit, give the costs and benefits of the system under monetary values. The system is evaluated against a benchmark, e.g., some wealth indexes of the measure of the private/public stream of social costs and benefits of alternative systems [115]. Rather than focusing on products, cost-benefit analysis is used for evaluating public or private investment proposals, e.g. by weighing the costs of the project against 
the expected benefits [114] (see [116] for a detailed comparison among LCA, life cycle costing and cost-benefit analysis). Other methods are at least conceptually close to LCA. For example, being a product-related tool that focuses on the flows associated with the production and consumption of a good, LCA is related to material flow analysis, though concentrating on product-related flows instead of region-related flows [114]. Multicriteria analysis is another widespread tool for sustainability assessment, which can be used when the evaluation needs to consider competing criteria. The method involves the collection of data about the perceived impacts (environmental, economic, social) by supply chain stakeholders [117] and preference synthesis through modeling algorithms [118]. Multicriteria analysis and LCA can usefully complement each other [119].

The sustainable transition towards sustainable agriculture and food systems should involve the evaluation of economic and social aspects. The possibility of integrating LCA within the more comprehensive LCSA framework would improve the suitability of the tool for sustainable development studies, as well as for applications in business, e.g., for supporting and communicating ecological innovation [28]. Greater research efforts to understand farmers' attitudes towards environmentally sound practices and technologies could suggest which interventions are most likely to be undertaken and which policies could be effective in promoting their adoption [120].

Author Contributions: Conceptualization, O.G.; Investigation, O.G., F.B., and F.V.; Writing—original draft preparation, O.G.; Writing-review and editing, O.G., F.B., and F.V.; Supervision, F.B. and A.Z.; Project administration, G.B. and A.P.; Funding acquisition, G.B., A.Z., and A.P.

Funding: This research was funded by the University of Pisa, project SALI (Strumenti di sostenibilità delle produzioni alimentari, Sustainability tools for food production) code PRA_2017_34.

Acknowledgments: The authors thank Silvia Coderoni, from Marche Polytechnic University, for useful comments to previous versions of the paper.

Conflicts of Interest: The authors declare no conflict of interest. The funders had no role in the design of the study; in the collection, analyses, or interpretation of data; in the writing of the manuscript, or in the decision to publish the results.

\section{References}

1. Van Tongeren, F. Agricultural Policy Design and Implementation. A Synthesis; Organisation for Economic Co-operation and Development: Paris, France, 2008; p. 32.

2. About the Sustainable Development Goals. Available online: https://www.un.org/ sustainabledevelopment/sustainable-development-goals/ (accessed on 9 October 2018).

3. Transforming Food and Agriculture to Achieve the SDGs; Food and Agricultural Organization of the United Nations: Rome, Italy, 2018; ISBN 978-92-5-130626-0.

4. Guinée, J.B.; Heijungs, R.; Huppes, G.; Zamagni, A.; Masoni, P.; Buonamici, R.; Ekvall, T.; Rydberg, T. Life Cycle Assessment: Past, Present, and Future. Environ. Sci. Technol. 2011, 45, 90-96. [CrossRef] [PubMed]

5. McManus, M.C.; Taylor, C.M. The changing nature of life cycle assessment. Biomass Bioenergy 2015, 82, 13-26. [CrossRef] [PubMed]

6. Sala, S.; Reale, F.; Cristobal-Garcia, J.; Pant, R. Life Cycle Assessment for the Impact Assessment of Policies; Publications Office: Luxembourg, 2016; ISBN 978-92-79-64813-7.

7. Reale, F.; Cinelli, M.; Sala, S. Towards a research agenda for the use of LCA in the impact assessment of policies. Int. J. Life Cycle Assess. 2017, 22, 1477-1481. [CrossRef]

8. Goedkoop, M.; Martinez, E.V.; de Beer, I. LCA as the Tool to Measure Progress towards the Sustainable Development Goals; LIST: Luxembourg, 2017.

9. Huang, H.; von Lampe, M.; van Tongeren, F. Climate change and trade in agriculture. Food Policy 2011, 36, S9-S13. [CrossRef]

10. Tsiboe, F.; Nalley, L.L.; Durand, A.; Greg, T.; Aaron, S. The Economic and Environmental Benefits of Sheath Blight Resistance in Rice. J. Agric. Resour. Econ. 2017, 42, 215-235.

11. AusLCI-The Australian Life Cycle Inventory Database Initiative. Available online: http://www.auslci. com.au/index.php/datasets/Agriculture (accessed on 9 October 2018). 
12. Agribalyse Program. Available online: https://www.ademe.fr/en/expertise/alternative-approaches-toproduction/agribalyse-program (accessed on 9 October 2018).

13. Viaggi, D. Research and innovation in agriculture: Beyond productivity? Bio-Based Appl. Econ. 2015, 4, 279-300.

14. Sonnemann, G.; Gemechu, E.D.; Sala, S.; Schau, E.M.; Allacker, K.; Pant, R.; Adibi, N.; Valdivia, S. Life Cycle Thinking and the Use of LCA in Policies Around the World. In Life Cycle Assessment; Hauschild, M.Z., Rosenbaum, R.K., Olsen, S.I., Eds.; Springer International Publishing: Cham, Switzerland, 2018; pp. $429-463$. ISBN 978-3-319-56474-6.

15. Roy, P.; Nei, D.; Orikasa, T.; Xu, Q.; Okadome, H.; Nakamura, N.; Shiina, T. A review of life cycle assessment (Lca) on some food products. J. Food Eng. 2009, 90, 1-10. [CrossRef]

16. Van Huis, A.; Oonincx, D.G.A.B. The environmental sustainability of insects as food and feed. A review. Agron. Sustain. Dev. 2017, 37, 43. [CrossRef]

17. Gnansounou, E.; Dauriat, A.; Villegas, J.; Panichelli, L. Life cycle assessment of biofuels: Energy and greenhouse gas balances. Bioresour. Technol. 2009, 100, 4919-4930. [CrossRef]

18. Gomiero, T.; Pimentel, D.; Paoletti, M.G. Environmental Impact of Different Agricultural Management Practices: Conventional vs. Organic Agriculture. Crit. Rev. Plant Sci. 2011, 30, 95-124. [CrossRef]

19. Martin, M.; Brandão, M. Evaluating the Environmental Consequences of Swedish Food Consumption and Dietary Choices. Sustainability 2017, 9, 2227. [CrossRef]

20. Rajagopal, D.; Vanderghem, C.; MacLean, H.L. Life Cycle Assessment for Economists. Annu. Rev. Resour. Econ. 2017, 9, 361-381. [CrossRef]

21. Freidberg, S. Calculating sustainability in supply chain capitalism. Econ. Soc. 2013, 42, 571-596. [CrossRef]

22. Benedetto, G.; Rugani, B.; Vázquez-Rowe, I. Rebound effects due to economic choices when assessing the environmental sustainability of wine. Food Policy 2014, 49, 167-173. [CrossRef]

23. Aleksandrowicz, L.; Green, R.; Joy, E.J.M.; Smith, P.; Haines, A. The Impacts of Dietary Change on Greenhouse Gas Emissions, Land Use, Water Use, and Health: A Systematic Review. PLoS ONE 2016, 11, e0165797. [CrossRef] [PubMed]

24. Clark, M.; Tilman, D. Comparative analysis of environmental impacts of agricultural production systems, agricultural input efficiency, and food choice. Environ. Res. Lett. 2017, 12, 064016. [CrossRef]

25. Notarnicola, B.; Sala, S.; Anton, A.; McLaren, S.J.; Saouter, E.; Sonesson, U. The role of life cycle assessment in supporting sustainable agri-food systems: A review of the challenges. J. Clean. Prod. 2017, 140, 399-409. [CrossRef]

26. Garnett, T. Three perspectives on sustainable food security: Efficiency, demand restraint, food system transformation. What role for life cycle assessment? J. Clean. Prod. 2014, 73, 10-18. [CrossRef]

27. Onat, N.; Kucukvar, M.; Halog, A.; Cloutier, S. Systems Thinking for Life Cycle Sustainability Assessment: A Review of Recent Developments, Applications, and Future Perspectives. Sustainability 2017, 9, 706. [CrossRef]

28. Zamagni, A.; Masoni, P.; Buttol, P.; Raggi, A.; Buonamici, R. Finding Life Cycle Assessment Research Direction with the Aid of Meta-Analysis. J. Ind. Ecol. 2012, 16, S39-S52. [CrossRef]

29. Hellweg, S.; Mila i Canals, L. Emerging approaches, challenges and opportunities in life cycle assessment. Science 2014, 344, 1109-1113. [PubMed]

30. Tillman, A.-M. Significance of decision-making for LCA methodology. Environ. Impact Assess. Rev. 2000, 20, 113-123.

31. Hiederer, R. International Reference Life Cycle Data System (ILCD) Handbook: General Guide for Life Cycle Assessment: Provisions and Action Steps; Publications Office: Luxembourg, 2011; ISBN 978-92-79-17451-3.

32. Sala, S.; Ciuffo, B.; Nijkamp, P. A systemic framework for sustainability assessment. Ecol. Econ. 2015, 119, 314-325.

33. Schaltegger, S. Economics of life cycle assessment: Inefficiency of the present approach. Bus. Strategy Environ. 1997, 6, 1-8. [CrossRef]

34. Zimmermann, P.; Frischknecht, R.; Ménard, M. Background Inventory Data. In Life Cycle Assessment (LCA) —Quo Vadis? Schaltegger, S., Braunschweig, A., Büchel, K., Dinkel, F., Frischknecht, R., Maillefer, C., Ménard, M., Peter, D., Pohl, C., Ros, M., et al., Eds.; Themenhefte Schwerpunktprogramm Umwelt; Birkhäuser Basel: Basel, Switzerland, 1996; pp. 39-49, ISBN 978-3-0348-9022-9. 
35. Baumann, H.; Tillman, A.-M. The Hitch Hikers's Guide to LCA: An Orientation in Life Cycle Assessment Methodology and Application; Studentlitteratur: Lund, Sweden, 2004; ISBN 978-91-44-02364-9.

36. Galli, A.; Wiedmann, T.; Ercin, E.; Knoblauch, D.; Ewing, B.; Giljum, S. Integrating Ecological, Carbon and Water footprint into a "Footprint Family" of indicators: Definition and role in tracking human pressure on the planet. Ecol. Indic. 2012, 16, 100-112. [CrossRef]

37. Ekvall, T.; Tillman, A.-M.; Molander, S. Normative ethics and methodology for life cycle assessment. J. Clean. Prod. 2005, 13, 1225-1234. [CrossRef]

38. Global Guidance Principles for Life Cycle Assessment Databases: A Basis for Greener Processes and Products: "Shonan Guidance Principles"; United Nations Environment Programme: Nairobi, Kenya, 2011.

39. Earles, J.M.; Halog, A. Consequential life cycle assessment: A review. Int. J. Life Cycle Assess. 2011, 16, 445-453. [CrossRef]

40. Schmidt, J.H.; Weidema, B.P. Shift in the marginal supply of vegetable oil. Int. J. Life Cycle Assess. 2008, 13, 235-239.

41. Van Stappen, F.; Mathot, M.; Decruyenaere, V.; Loriers, A.; Delcour, A.; Planchon, V.; Goffart, J.-P.; Stilmant, D. Consequential environmental life cycle assessment of a farm-scale biogas plant. J. Environ. Manag. 2016, 175, 20-32.

42. Rajagopal, D. Consequential Life Cycle Assessment of Policy Vulnerability to Price Effects: CLCA of Policy Vulnerability to Price Effects. J. Ind. Ecol. 2014, 18, 164-175.

43. Weidema, B.P.; Ekvall, T.; Heijungs, R. Guidelines for Application of Deepened and Broadened LCA-Deliverable D18 of Work Packag e 5 of the CALCAS Project; CALCAS-Co-ordination Action for innovation in Life-Cycle Analysis for Sustainability: Colorado Springs, CO, USA, 2009; p. 49.

44. Rajagopal, D.; Zilberman, D. On market-mediated emissions and regulations on life cycle emissions. Ecol. Econ. 2013, 90, 77-84. [CrossRef]

45. Weidema, B.P. Market Information in Life Cycle Assessment; Danish Environmental Protection Agency: København, Denmark, 2003; p. 147.

46. Weidema, B.P.; Pizzol, M.; Schmidt, J.; Thoma, G. Attributional or consequential Life Cycle Assessment: A matter of social responsibility. J. Clean. Prod. 2018, 174, 305-314. [CrossRef]

47. Brander, M.; Tipper, R.; Hutchison, C.; Davis, G. Consequential and Attributional Approaches to Lca: A Guide to Policy Makers with Specific Reference to Greenhouse Gas Lca of Biofuels; Technical Paper; Ecometrica, 2009. Available online: https:/ / ecometrica.com/white-papers/consequential-and-attributional-approachesto-lca-a-guide-to-policy-makers-with-specific-reference-to-greenhouse-gas-lca-of-biofuels (accessed on 4 December 2018).

48. Ekvall, T.; Azapagic, A.; Finnveden, G.; Rydberg, T.; Weidema, B.P.; Zamagni, A. Attributional and consequential LCA in the ILCD handbook. Int. J. Life Cycle Assess. 2016, 21, 293-296. [CrossRef]

49. Creutzig, F.; Popp, A.; Plevin, R.; Luderer, G.; Minx, J.; Edenhofer, O. Reconciling top-down and bottom-up modelling on future bioenergy deployment. Nat. Clim. Chang. 2012, 2, 320-327. [CrossRef]

50. Baitz, M.; Albrecht, S.; Brauner, E.; Broadbent, C.; Castellan, G.; Conrath, P.; Fava, J.; Finkbeiner, M.; Fischer, M.; Fullana i Palmer, P.; et al. LCA's theory and practice: Like ebony and ivory living in perfect harmony? Int. J. Life Cycle Assess. 2013, 18, 5-13. [CrossRef]

51. Reimann, K.; Finkbeiner, M.; Horvath, A.; Matsuno, Y. Evaluation of Environmental Life Cycle Approaches for Policy and Decision Making Support in Micro and Macro Level Applications; European Commission, Joint Research Centre, Institute for Evironment and Sustainability: Copenhagen, Denmark, 2010; p. 188.

52. Tukker, A.; Huppes, G.; van Oers, L.; Heijungs, R. Environmentally Extended input-Output Tables and Models for Europe; Eutopean Commission, Joint Research Centre, Institute for Prospective Technological Studies: Seville, Spain, 2010; p. 120.

53. Garnett, T. Where are the best opportunities for reducing greenhouse gas emissions in the food system (including the food chain)? Food Policy 2011, 36, S23-S32. [CrossRef]

54. Silvenius, F.; Katajajuuri, J.-M.; Grönman, K.; Soukka, R.; Koivupuro, H.-K.; Virtanen, Y. Role of Packaging in LCA of Food Products. In Towards Life Cycle Sustainability Management; Finkbeiner, M., Ed.; Springer Netherlands: Dordrecht, The Netherlands, 2011; pp. 359-370. ISBN 978-94-007-1898-2.

55. Ferrara, C.; De Feo, G. Life Cycle Assessment Application to the Wine Sector: A Critical Review. Sustainability 2018, 10, 395. [CrossRef] 
56. Vázquez-Rowe, I.; Villanueva-Rey, P.; Moreira, M.T.; Feijoo, G. Environmental analysis of Ribeiro wine from a timeline perspective: Harvest year matters when reporting environmental impacts. J. Environ. Manag. 2012, 98, 73-83. [CrossRef]

57. Godfray, H.C.J.; Beddington, J.R.; Crute, I.R.; Haddad, L.; Lawrence, D.; Muir, J.F.; Pretty, J.; Robinson, S.; Thomas, S.M.; Toulmin, C. Food Security: The Challenge of Feeding 9 Billion People. Science 2010, 327, 812-818. [CrossRef]

58. Meier, M.S.; Stoessel, F.; Jungbluth, N.; Juraske, R.; Schader, C.; Stolze, M. Environmental impacts of organic and conventional agricultural products-Are the differences captured by life cycle assessment? J. Environ. Manag. 2015, 149, 193-208. [CrossRef]

59. Herrero, M.; Henderson, B.; Havlík, P.; Thornton, P.K.; Conant, R.T.; Smith, P.; Wirsenius, S.; Hristov, A.N.; Gerber, P.; Gill, M.; et al. Greenhouse gas mitigation potentials in the livestock sector. Nat. Clim. Chang. 2016, 6, 452-461. [CrossRef]

60. Blengini, G.A.; Busto, M. The life cycle of rice: LCA of alternative agri-food chain management systems in Vercelli (Italy). J. Environ. Manag. 2009, 90, 1512-1522. [CrossRef] [PubMed]

61. Bryngelsson, D.; Wirsenius, S.; Hedenus, F.; Sonesson, U. How can the EU climate targets be met? A combined analysis of technological and demand-side changes in food and agriculture. Food Policy 2016, 59, 152-164. [CrossRef]

62. Policies to Encourage Sustainable Consumption: Full Report; Publications Office: Luxembourg, 2012; ISBN 978-92-79-25952-4.

63. Garnett, T. Plating up solutions. Science 2016, 353, 1202-1204. [CrossRef] [PubMed]

64. Vieux, F.; Soler, L.-G.; Touazi, D.; Darmon, N. High nutritional quality is not associated with low greenhouse gas emissions in self-selected diets of French adults. Am. J. Clin. Nutr. 2013, 97, 569-583. [CrossRef]

65. Perignon, M.; Vieux, F.; Soler, L.-G.; Masset, G.; Darmon, N. Improving diet sustainability through evolution of food choices: Review of epidemiological studies on the environmental impact of diets. Nutr. Rev. 2017, 75, 2-17. [CrossRef] [PubMed]

66. Friedman, A.L.; Miles, S. Stakeholders: Theory and Practice; Oxford University Press: Oxford, UK; New York, NY, USA, 2006; ISBN 978-0-19-926987-7.

67. Dwivedi, S.L.; Lammerts van Bueren, E.T.; Ceccarelli, S.; Grando, S.; Upadhyaya, H.D.; Ortiz, R. Diversifying Food Systems in the Pursuit of Sustainable Food Production and Healthy Diets. Trends Plant Sci. 2017, 22, 842-856. [CrossRef]

68. Garnett, T. Livestock-related greenhouse gas emissions: Impacts and options for policy makers. Environ. Sci. Policy 2009, 12, 491-503. [CrossRef]

69. Röös, E.; Patel, M.; Spångberg, J.; Carlsson, G.; Rydhmer, L. Limiting livestock production to pasture and by-products in a search for sustainable diets. Food Policy 2016, 58, 1-13. [CrossRef]

70. Rajagopal, D. On mitigating emissions leakage under biofuel policies. GCB Bioenergy 2016, 8, 471-480. [CrossRef]

71. Metcalf, G.E.; Weisbach, D.A. The Design of a Carbon Tax. Harv. Environ. Law Rev. 2009, 33, 499-556. [CrossRef]

72. Walls, M. Extended Producer Responsibility and Product Design: Economic Theory and Selected Case Studies; Resource for the Future: Washington, DC, USA, 2006.

73. Greening. Available online: https://ec.europa.eu/agriculture/direct-support/greening_en (accessed on 9 October 2018).

74. Zilberman, D.; Zhao, J.; Heiman, A. Adoption Versus Adaptation, with Emphasis on Climate Change. Annu. Rev. Resour. Econ. 2012, 4, 27-53. [CrossRef]

75. Caswell, J.A.; Mojduszka, E.M. Using Informational Labeling to Influence the Market for Quality in Food Products. Am. J. Agric. Econ. 1996, 78, 1248-1253. [CrossRef]

76. Gadema, Z.; Oglethorpe, D. The use and usefulness of carbon labelling food: A policy perspective from a survey of UK supermarket shoppers. Food Policy 2011, 36, 815-822. [CrossRef]

77. Leach, A.M.; Emery, K.A.; Gephart, J.; Davis, K.F.; Erisman, J.W.; Leip, A.; Pace, M.L.; D’Odorico, P.; Carr, J.; Noll, L.C.; et al. Environmental impact food labels combining carbon, nitrogen, and water footprints. Food Policy 2016, 61, 213-223. [CrossRef]

78. Akaichi, F.; Nayga, R.M.; Nalley, L.L. Are there trade-offs in valuation with respect to greenhouse gas emissions, origin and food miles attributes? Eur. Rev. Agric. Econ. 2017, 44, 3-31. [CrossRef] 
79. Boons, F.; Baumann, H.; Hall, J. Conceptualizing sustainable development and global supply chains. Ecol. Econ. 2012, 83, 134-143. [CrossRef]

80. Jeswani, H.K.; Azapagic, A.; Schepelmann, P.; Ritthoff, M. Options for broadening and deepening the LCA approaches. J. Clean. Prod. 2010, 18, 120-127. [CrossRef]

81. Halloran, A.; Clement, J.; Kornum, N.; Bucatariu, C.; Magid, J. Addressing food waste reduction in Denmark. Food Policy 2014, 49, 294-301. [CrossRef]

82. Castellani, V.; Sala, S.; Benini, L. Hotspots analysis and critical interpretation of food life cycle assessment studies for selecting eco-innovation options and for policy support. J. Clean. Prod. 2017, 140, 556-568. [CrossRef]

83. Venturi, F.; Sanmartin, C.; Taglieri, I.; Xiaoguo, Y.; Andrich, G.; Zinnai, A. The influence of packaging on the sensorial evolution of white wine as a function of the operating conditions adopted during storage. Agrochimica 2016, 60, 150-160.

84. Shmelev, S.E.; Powell, J.R. Ecological-economic modelling for strategic regional waste management systems. Ecol. Econ. 2006, 59, 115-130. [CrossRef]

85. Yang, Y.-H.; Lin, S.-J.; Lewis, C. Reduction of acidification from electricity-Generating industries in Taiwan by Life Cycle Assessment and Monte Carlo optimization. Ecol. Econ. 2009, 68, 1575-1582. [CrossRef]

86. Mouron, P.; Scholz, R.W.; Nemecek, T.; Weber, O. Life cycle management on Swiss fruit farms: Relating environmental and income indicators for apple-growing. Ecol. Econ. 2006, 58, 561-578. [CrossRef]

87. Settanni, E.; Notarnicola, B.; Tassielli, G. Combining Life Cycle Assessment of food products with economic tools. In Environmental Assessment and Management in the Food Industry; Woodhead Publishing Limited: Sawston, UK, 2010; pp. 207-218, ISBN 978-1-84569-552-1.

88. Suh, S. Functions, commodities and environmental impacts in an ecological-economic model. Ecol. Econ. 2004, 48, 451-467. [CrossRef]

89. Ghertner, D.A.; Fripp, M. Trading away damage: Quantifying environmental leakage through consumption-based, life-cycle analysis. Ecol. Econ. 2007, 63, 563-577. [CrossRef]

90. Engström, R.; Wadeskog, A.; Finnveden, G. Environmental assessment of Swedish agriculture. Ecol. Econ. 2007, 60, 550-563. [CrossRef]

91. Cantono, S.; Heijungs, R.; Kleijn, R. Environmental Accounting of Eco-innovations through Environmental Input-Output Analysis: The Case of Hydrogen and Fuel Cells Buses. Econ. Syst. Res. 2008, 20, 303-318. [CrossRef]

92. Hendrickson, C.T.; Lave, L.B.; Matthews, H.S. Environmental Life Cycle Assessment of Goods and Services: An Input-Output Approach; RFF Press Resources for the Future: Washington, DC, USA, 2006; ISBN 978-1-933115-23-8.

93. Sueyoshi, T.; Yuan, Y.; Goto, M. A literature study for DEA applied to energy and environment. Energy Econ. 2017, 62, 104-124. [CrossRef]

94. Vázquez-Rowe, I.; Iribarren, D. Review of Life-Cycle Approaches Coupled with Data Envelopment Analysis: Launching the CFP + DEA Method for Energy Policy Making. Sci. World J. 2015, 2015, 1-10. [CrossRef]

95. Dakpo, K.H.; Jeanneaux, P.; Latruffe, L. Greenhouse gas emissions and efficiency in French sheep meat farming: A non-parametric framework of pollution-adjusted technologies. Eur. Rev. Agric. Econ. 2017, 44, 33-65. [CrossRef]

96. Wang, B.; Brême, S.; Moon, Y.B. Hybrid modeling and simulation for complementing Lifecycle Assessment. Comput. Ind. Eng. 2014, 69, 77-88. [CrossRef]

97. Kloepffer, W. Life cycle sustainability assessment of products: (with Comments by Helias A. Udo de Haes, p. 95). Int. J. Life Cycle Assess. 2008, 13, 89-95. [CrossRef]

98. Zamagni, A. Life cycle sustainability assessment. Int. J. Life Cycle Assess. 2012, 17, 373-376. [CrossRef]

99. Onozaka, Y.; Mcfadden, D.T. Does Local Labeling Complement or Compete with Other Sustainable Labels? A Conjoint Analysis of Direct and Joint Values for Fresh Produce Claim. Am. J. Agric. Econ. 2011, 93, 693-706. [CrossRef]

100. Sirieix, L.; Delanchy, M.; Remaud, H.; Zepeda, L.; Gurviez, P. Consumers' perceptions of individual and combined sustainable food labels: A UK pilot investigation: Consumers' perceptions of sustainable food labels. Int. J. Consum. Stud. 2013, 37, 143-151. [CrossRef]

101. Ben Youssef, A.; Abderrazak, C. Multiplicity of Eco-Labels, Competition, and the Environment. J. Agric. Food Ind. Organ. 2009, 7. [CrossRef] 
102. Grunert, K.G.; Hieke, S.; Wills, J. Sustainability labels on food products: Consumer motivation, understanding and use. Food Policy 2014, 44, 177-189. [CrossRef]

103. Apostolidis, C.; McLeay, F. Should we stop meating like this? Reducing meat consumption through substitution. Food Policy 2016, 65, 74-89. [CrossRef]

104. Peano, C.; Baudino, C.; Tecco, N.; Girgenti, V. Green marketing tools for fruit growers associated groups: Application of the Life Cycle Assessment (LCA) for strawberries and berry fruits ecobranding in northern Italy. J. Clean. Prod. 2015, 104, 59-67. [CrossRef]

105. Alberti, M.; Caini, L.; Calabrese, A.; Rossi, D. Evaluation of the costs and benefits of an environmental management system. Int. J. Prod. Res. 2000, 38, 4455-4466. [CrossRef]

106. Fai Pun, K. Determinants of environmentally responsible operations: A review. Int. J. Qual. Reliab. Manag. 2006, 23, 279-297. [CrossRef]

107. Van Dooren, C.; Marinussen, M.; Blonk, H.; Aiking, H.; Vellinga, P. Exploring dietary guidelines based on ecological and nutritional values: A comparison of six dietary patterns. Food Policy 2014, 44, 36-46. [CrossRef]

108. Heijungs, R.; Koning, A.; Suh, S.; Huppes, G. Toward an Information Tool for Integrated Product Policy: Requirements for Data and Computation. J. Ind. Ecol. 2006, 10, 147-158. [CrossRef]

109. Weber, C.L.; Matthews, H.S. Quantifying the global and distributional aspects of American household carbon footprint. Ecol. Econ. 2008, 66, 379-391. [CrossRef]

110. Wiedmann, T.; Wilting, H.C.; Lenzen, M.; Lutter, S.; Palm, V. Quo Vadis MRIO? Methodological, data and institutional requirements for multi-region input-output analysis. Ecol. Econ. 2011, 70, 1937-1945. [CrossRef]

111. Molinos-Senante, M.; Hernández-Sancho, F.; Mocholí-Arce, M.; Sala-Garrido, R. Economic and environmental performance of wastewater treatment plants: Potential reductions in greenhouse gases emissions. Resour. Energy Econ. 2014, 38, 125-140. [CrossRef]

112. Wood, R.; Lenzen, M. Structural path decomposition. Energy Econ. 2009, 31, 335-341. [CrossRef]

113. Singh, R.K.; Murty, H.R.; Gupta, S.K.; Dikshit, A.K. An overview of sustainability assessment methodologies. Ecol. Indic. 2012, 15, 281-299. [CrossRef]

114. Ness, B.; Urbel-Piirsalu, E.; Anderberg, S.; Olsson, L. Categorising tools for sustainability assessment. Ecol. Econ. 2007, 60, 498-508. [CrossRef]

115. Kopp, R.; Krupnick, A.; Toman, M. Cost-benefit analysis and regulatory reform. Hum. Ecol. Risk Assess. Int. J. 1997, 3, 787-852. [CrossRef]

116. Hoogmartens, R.; Van Passel, S.; Van Acker, K.; Dubois, M. Bridging the gap between LCA, LCC and CBA as sustainability assessment tools. Environ. Impact Assess. Rev. 2014, 48, 27-33. [CrossRef]

117. French, S. A manifesto for the new MCDA era. J. Multi-Criteria Decis. Anal. 1993, 2, 125-127. [CrossRef]

118. Bartolini, F.; Viaggi, D. Recent developments in multi-criteria evaluation of regulations: Recent developments in multi-criteria evaluation. Qual. Assur. Saf. Crop. Foods 2010, 2, 182-196. [CrossRef]

119. De Luca, A.I.; Iofrida, N.; Leskinen, P.; Stillitano, T.; Falcone, G.; Strano, A.; Gulisano, G. Life cycle tools combined with multi-criteria and participatory methods for agricultural sustainability: Insights from a systematic and critical review. Sci. Total Environ. 2017, 595, 352-370. [CrossRef] [PubMed]

120. Lefebvre, M.; Espinosa, M.; Gomez y Paloma, S.; Paracchini, M.L.; Piorr, A.; Zasada, I. Agricultural landscapes as multi-scale public good and the role of the Common Agricultural Policy. J. Environ. Plan. Manag. 2015, 58, 2088-2112. [CrossRef]

(C) 2018 by the authors. Licensee MDPI, Basel, Switzerland. This article is an open access article distributed under the terms and conditions of the Creative Commons Attribution (CC BY) license (http:/ / creativecommons.org/licenses/by/4.0/). 